\title{
Philosophical Reflections: Cognitive, Political and Social Aspects
}

\author{
VYTIS VALATKA \\ Department of Philosophy and Cultural Studies, Vilnius Gediminas Technical University, 1 Trakų Street, 01132 Vilnius, Lithuania \\ Email:vytis.valatka@vilniustech.It
}

\begin{abstract}
This article explores various interlinks and connections between philosophy and the other sciences, namely, linguistics, cognitive sciences, sociology, economy, political, ideological and human life studies. Those interlinks and connections are analysed within three methodological paradigms. The first paradigm binds cognising, defining and speaking. The second paradigm integrates assembling, self-organising and social engineering. The third one connects working, living and sensing together. According to the aforementioned paradigms, this issue is divided into three chapters. This article, in turn, delivers concise presentations of articles belonging to the above-mentioned chapters. Those presentations interlink various issues of different sciences, such as solving paradoxes of knowability, delivering reliable definitions of transdisciplinary knowledge, identifying means and mechanisms of linguistic subjectivity, proposing effective ways and procedures of self-organization of democracy, discovering relevant methods of social engineering for strengthening democratic welfare state, offering feasible scenarios of Europeanization processes, establishing balance between work, recreation and health, and identifying common sense phenomenon with social life-world.
\end{abstract}

Keywords: philosophy, linguistics, cognitive sciences, sociology, economy, political, ideological and human life studies, paradigm

From the very beginning of its existence philosophy retains the status of intellectual field where various cognitive, psychological, anthropological, social, ethical, political and similar problems meet and are being discussed. Therefore different sides and facets of different things, matters, phenomena, occurrences and events of physical, anthropological and social reality step into the realm of philosophical considerations. Nevertheless, philosophy is not capable of solving of the above-mentioned issues. To demand this task from philosophy is to miss its proper target. As a matter of fact, philosophy should not be regarded as the space of/for the concrete answers to the concrete questions or problems. Contrariwise, it is a realm of actual questions and raising relevant problems, the answers and solutions to which vary depending on the current space, epoch and time.

So, philosophy interconnects with many various sciences. For example, logic delivers rules of correct reasoning. Epistemology, in turn, deals with laws of human cognition and knowledge. Those laws and rules can serve as instruments for analysis of issues peculiar to cognitive and linguistic sciences including paradoxes of knowability, definitions of transdisciplinary knowledge, means and mechanisms of realization of linguistic subjectivity and so 
on. The same laws and rules can also contribute to considerations of relevant political and social issues, namely, effective ways and procedures of self-organization of democracy, relevant methods of social engineering for strengthening democratic welfare state, feasible scenarios of Europeanization processes, establishing balance between work, recreation and health, identifying common sense phenomenon with social life-world, etc.

Manifold interlinks between philosophy, economics, cognitive sciences, sociology, political, ideological and human life studies, linguistics and the other sciences were investigated recently by Scheuer, Maziarz (2019), Drekalovic (2020), Carpentier, Doudaki (2019), Mazur, Duchlinski (2020), Aramayo (2019), Darginavičienè (2018), etc. In this issue, those interlinks are analysed in three chapters based on three methodological paradigms. The first paradigm binds cognising, defining and speaking. The second paradigm integrates assembling, self-organising and social engineering. The third one connects working, living and sensing.

The first paradigm includes reflections on logical, cognitive and linguistic issues. One of the actual issues of contemporary logics is the principle of knowability asserting that every true proposition may be known. Actually, this principle leads to the problem known as Church-Fitch paradox maintaining that all the true propositions are known. In the article Knowability Without Rigidity the author analyses the existing trials to solve this paradox while maintaining the validity of principle of knowability. Such an analysis is based on works of Brogaard, Salerno (2019), Dummet (2009), Edgington (1985; 2010), Ruckert (2004), Jenkins (2007), Proietti (2016), etc. The author notices that the majority of the above-mentioned trials are based on rigidification of certain aspects of what is knowable. More to say, these trials also involve counterintuitive consequences. The author concentrates on the interpretations of knowability principle proposed by Edgington, Ruckert and Jenkins. He indentifies positive and negative sides of these interpretations coming to the conclusion that all of them are insufficient to solve the Church-Fitch paradox. Finally, the author's own interpretation of knowability principle is offered that claims to be both free from rigiditifications and to avoid the Church-Fitch paradox. According to this interpretation, a true proposition is knowable if it is possible to know that it can hold.

Contemporary scientific knowledge possesses a strong transdisciplinary aspect. Yet, it still lacks the concrete and clear definition of the phenomenon of transdisplinarity itself. The article Issues of Definition and Potentialities of Transdisciplinary Approach in Post-non-classical Science tries to fill this significant gap. The author of the article presents a comprehensive analysis of this phenomenon, comparing and relating it to the other phenomena of integration of scientific knowledge, such as interdisciplinarity and multidisciplinarity. The relations between scientific transdisciplinarity and nonscientific forms of knowledge are also being investigated. This analysis mainly rests on works of Frodeman, Klein, Mitcham (2010), Nicolescu (2006), Di Giulio, Defila (2017), Piaget (1970), Lawrence (2014), etc. The author comes to the conclusion that transdisciplinary science extends the principles of classical and non-classical science to post-non-classical rationality. Another important conclusion is that unlike particular disciplines that study specific fragments or levels of reality, a transdisciplinary strategy is an attempt to understand the dynamics of the process at several levels of reality at the same time. Therefore transdisciplinarity crosses the boundaries of specific disciplines and creates a universal picture of the process under investigation.

Postmodern philosophy has strong interconnections with linguistic studies. These interconnections are witnessed by the term 'linguistic turn' denoting the significant event that took place in philosophy in the 20th century. One of the most important issues of contemporary 
linguistic philosophy is the phenomenon of linguistic subjectivity. The article Means and Mechanism of the Realization of Linguistic Subjectivity from the Perspective of Philosophical Cognition is dedicated to this particular phenomenon. The author of the article basing his reflections on the works of Nicholas (2015), Langacker (2019), Traugott (2019), Turner (2019), Vella, Gualeni 2019) etc. analyses the phenomenon of linguistic subjectivity from the perspective of philosophical cognition. He proposes the original interactive geometric research framework of language subjectivity that allows him to explore the means and mechanism of realization of this phenomenon at six levels: language system level, language use level, propositional meaning level, non-propositional meaning level, speaker's encoded meaning level, and hearer's decoded meaning level. The author also identifies the main subjective factors behind the speaker's words, utterances or discourse, namely, attitudes, emotions and feelings.

The second paradigm interconnects political and moral issues. Contemporary political philosophy, among various relevant problems, investigates nature, principles, institutions, processes and procedures of modern democracy. The article Social Phenomenology as a Factor of Self-organization of Democracy concentrates on one of the most important aspects of democracy, namely, the process of its self-organizing. The author of the article basing his considerations on works of Parsons (1971), Ginsburg et al. (2018), Shaw (2011), Hobson (2015), De Oliveira (2010) and the others scrutinizes structurally functional, axiological and phenomenological approaches to the essence of democracy. Such an analysis leads to the conclusion that democracy as a social and political phenomenon has a strong phenomenological dimension. More specifically, the fundaments of self-organising of democracy are important elements of social phenomenology, namely, social feelings (solidarity, responsibility, voluntariness, openness, respect, tolerance, honesty, humaneness, etc.) as well as moral, social and political values (freedom, common good, civil peace, rule of law, justice, democratic competition, the plurality of values, etc.). These elements legitimise and establish various democratic institutions, for example, free and fair elections, multiparty system, separation of powers, control of the government and the others.

Among the significant objects of postmodern political studies, great attention is paid to relations among various forms of democracy, technocracy and social engineering. The article In the Path of Vydunas: Moral Values and Social Engineering as the Tool for the Welfare State Creation analyses the possibilities of collaboration and cooperation between democracy and technocracy in the process of creating, establishing and strengthening welfare state. The author of the article, concentrating mainly on works of Vydūnas (1923), Schelsky (1961), Gunnel (1982), McClure (2018), Spencer (2018), etc., distinguishes two types of technocracy, namely technocracy in a narrow sense excluding actual questions of moral character and technocracy in a wide sense involving the above-mentioned questions. The greatest attention is given to the second type that is interpreted as the social engineering resting on the interdisciplinary discussion of experts concerning the most relevant social, economical, political and similar questions linked to moral values. The article comes to the conclusion that technocracy taken in this wide sense should not be opposed to democracy, as moral as well as democratic ideals and values such as freedom, equality, justice, common good, etc. are the essential landmarks for social engineering in the processes of creating, establishing and strengthening contemporary welfare state.

Contemporary European social, political and ideological studies deliver much attention to the analysis of the phenomena and processes of European identity, Europaneity and Europeanization. Such an analysis tries to identify the main features, aspects, principles, factors and actors of the above-mentioned phenomena and processes as well as to propose feasible 
strategies and future scenarios. The article The European Assemblage: A Discursive-Material Analysis of European Identity, Europaneity and Europeanisation is a representative example of an analysis of that type. The author bases his considerations essentially on the works of Jaspers (1947), Habermas (2001), Galpin (2017), Risse (2010), Delanty and Rumford (2005), etc. Differently from prevailing approaches to European identity, Europeanism and Europeanisation, emphasising their material components, the article applies comprehensive and integrative discursive-material investigation interpreting both material and discursive elements of the aforementioned phenomena from the perspective of horizontal relations. This investigation leads to the conclusion that the authentic understanding of Europe presents this geographical, cultural, political, economical, etc. space as an assemblage, performed in always unique and contingent articulations of various discursive and material components.

The third perspective brings together economical, sociological topics as well as issues of human life studies. In the global society of the end of 20th century - the beginning of 21 st century we can observe a significant phenomenon that can be entitled as the rise of creative class (Florida 2002). One of social groups representing this creative class is the group of the socalled knowledge workers. The article The Relation Between Work and Thumos. A Critical Interrogation of the Motivation Behind Knowledge Work Compulsion concentrates on the essential challenge that the knowledge workers meet in their everyday life. It is a paradoxical situation that can be called a voluntary compulsive work. More concretely, knowledge workers do not work to live, on the contrary, they voluntarily live to work. That leads to one more paradox since the overinvestment in knowledge work does not appear to generate proportionate gains for the working subject, for example, high quality leisure, increased health or wellbeing. The author of the article, based on works of Fukuyama (1992), Verhaeghe (2012), Han (2017), Sennett (2006), Yusoff, Kian et al. (2013), etc. tries to identify the reasons of voluntary motivation for such a compulsive work. The answer is found in Fukayama's interpretation of Plato's conception of thumos - the part of human soul that seeks recognition and honour over security. In other words, the article comes to the conclusion that knowledge work possesses a strong thumotic origin.

Anthropological, cultural and sociological studies of 20 th and 21 st centuries pay a significant attention to the analysis of ways, modes and styles of human life as well as to spaces, places and contexts it occupies. Contemporary social phenomenology enters this analysis concentrating on the life-worlds of society as well as of social groups and individuals which constitute that society. The article The Phenomenon of Common Sense and the Thinking of Alfred Schutz scrutinizes the concept of life-world presented in the phenomenology of the social world of A. Schutz, one of the most famous phenomenologists of the 20th century. The author of the article mainly rests on works of Schutz himself (1953; 1967), Bierstedt (1963), Gurwitsch (1966), Luckmann (1973), Natanson (1986), etc. His analysis draws an original conclusion that, from the perspective of Schutz's thinking, the phenomenon of life-world is identical to the phenomenon of common sense. More to say, those phenomena are the same as the phenomena of typification and com-

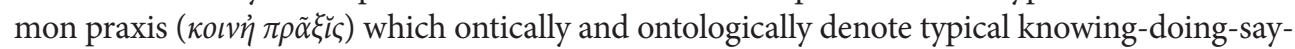
ing of the whole society and its groups. All the above-mentioned phenomena also mean Verstehen, mundane experiencing, or everyday transcending.

\section{CONCLUSIONS}

Philosophy can be considered as universal intellectual field where various cognitive, psychological, anthropological, social, ethical, political and similar problems meet and are being discussed. That is, different sides and facets of different things, matters, phenomena, occurrences 
and events of physical, anthropological and social reality step into the realm of philosophical considerations. Hence, philosophy interlinks with many various sciences, such as linguistics, cognitive sciences, sociology, economy, political, ideological and human life studies, etc. These interlinks may be investigated within various methodological paradigms that include methods, rules, principles and the other cognitive tools of the sciences interlinked. As for these paradigms, they open a wide space for philosophical reflections that relate and connect relevant issues of various sciences, such as solving paradoxes of knowability, delivering reliable definitions of transdisciplinary knowledge, identifying means and mechanisms of realization of linguistic subjectivity, proposing effective ways and procedures of self-organization of democracy, discovering relevant methods of social engineering for strengthening democratic welfare state, offering feasible scenarios of Europeanization processes, establishing balance between work, recreation and health, and identifying the common sense phenomenon with social life-world.

\section{References}

1. Aramayo, R. R. 2019. 'Diderot's Criticism of Colonialism: Plea for Equality and Reciprocity Among Peoples', Philosophy. Sociology 30(1): 63-70.

2. Bierstedt, R. 1963. 'Review: The Common Sense World of Alfred Schutz', Social Research 30(1): 116-121.

3. Brogaard, B.; Salerno, J. 2019. 'Fitch's Paradox of Knowability', in The Stanford Encyclopedia of Philosophy, ed. E. N. Zalta. Available at: https://plato.stanford.edu/entries/fitch-paradox/ (accessed: 01.11.2019).

4. Carpentier, N.; Doudaki, V. 2019. 'The Construction of the Homeless as a Discursive-Political Struggle: A Discursive-Theoretical Re-reading of the Homeless Subject Position', Philosophy. Sociology 30(1): 71-79.

5. Darginavičienè, I. 2018. 'The Influence of Culture and Language on the Identity of a Person', Logos (Vilnius) 95: 164-176.

6. Delanty, G.; Rumford, Ch. 2005. Rethinking Europe: Social Theory and the Implications of Europeanization. London and New York: Routledge.

7. De Oliveira, N. 2010. 'Towards a Phenomenology of Liberation: a Critical Theory of Race and the Fate of Democracy in Latin America,' Veritas 55(1): 206-226.

8. Di Giulio, A.; Defila, R. 2017. 'Enabling University Educators to Equip Students with Inter- and Transdisciplinary Competencies', International Journal of Sustainability in Higher Education 18(5): 130-147.

9. Drekalovic, V.2020.'The Role of Mathematical Toolsin Scientific Phenomenon Explanation-A Guarantee of Reliability or a Pillar of False Credibility?', Philosophy. Sociology 31(1): 85-93.

10. Dummett, M. 2009. 'Fitch's Paradox of Knowability', in New Essays on the Knowability Paradox, ed. J. Salerno. Oxford: Oxford University Press, 51-52.

11. Edgington, D. 1985. 'The Paradox of Knowability', Mind 94: 557-568.

12. Edgington, D. 2010. 'Possible Knowledge of Unknown Truth', Synthese 173: 41-52.

13. Florida, R. 2002. The Rise of the Creative Class: And How It's Transforming Work, Leisure, Community and Everyday Life. New York: Basic Books.

14. Frodeman, R.; Klein, J. T.; Mitcham, C. 2010. The Oxford Handbook of Interdisciplinarity. Oxford: Oxford University Press.

15. Fukuyama, F. 1992. The End of History and the Last Man. New York: The Free Press.

16. Galpin, Ch. 2017. The Euro Crisis and European Identities Political and Media Discourse in Germany, Ireland and Poland. Basingstoke: Palgrave Macmillan.

17. Ginsburg, T.; Hug, A. Z.; Versteeg, M. 2018. 'The Coming Demise of Liberal Constitutionalism?', University of Chicago Law Review 85(2): 239-255.

18. Gunnell, J. G. 1982. 'The Technocratic Image and the Theory of Technocracy', Technology and Culture 23(3): 392-416.

19. Gurwitsch, A. 1966. 'Introduction', in Collected Papers III: Studies in Phenomenological Philosophy, ed. I. Schutz. The Hague: Martinus Nijhoff, xi-xxxi.

20. Habermas, J. 2001. The Postnational Constellation: Political Essays. Cambridge: Polity Press.

21. Han, B-C. 2017. Psychopolitics: Neoliberalism and New Technologies of Power. London: Verso. 
22. Hobson, C. 2015. The Rise of Democracy: Revolution, War and Transformations in International Politics Since 1776. Edinburgh: University Press.

23. Jaspers, K. 1947. Vom europäischen Geist: Vortrag gehalten bei den Rencontres Internationales de Genève. Munich: Piper.

24. Jenkins, C. S. 2007. 'Anti-realism and Epistemic Accessibility', Philosophical Studies: An International Journal for Philosophy in the Analytic Tradition 132: 525-551.

25. Langacker, R. W. 2019. 'Levels of Reality', Languages 4(2): 1-20.

26. Lawrence, R. J. 2004. 'Housing and Health: From Interdisciplinary Principles to Transdisciplinary Research and Practice', Futures 36(4): 487-502.

27. Luckmann, T. 1973. The Structures of the Life-World. Evanston: Northwestern University Press.

28. Mazur, P. S.; Duchlinski, P. 2020. 'Credibility and Creativity in Network Society', Creativity Studies 13(1): 53-63.

29. McClure, P. K. 2018. "You're Fired", Says the Robot: The Rise of Automation in the Workplace, Technophobes, and Fears of Unemployment', Social Science Computer Review 36(2): 139-156.

30. Natanson, M. 1986. Anonymity: A Study in the Philosophy of Alfred Schutz. Bloomington: Indiana University Press.

31. Nicholas, G. 2015. Mind, Language and Subjectivity. New York: Routledge.

32. Nicolescu, B. 2006. 'Heisenberg and the Levels of Reality', European Journal of Science and Theology 2(1): 9-19.

33. Parsons, T. 1971. The System of Modern Societies. Englewood Cliffs, N. J.: Prentice-Hall.

34. Piaget, J. 1970. 'General Problems of Interdisciplinary Research and Common Mechanisms', in Main Trends of Research in the Social and Human Sciences, pt. 1: The Social Sciences. Paris: UNESCO, 467-528.

35. Proietti, C. 2016. 'The Fitch-Church Paradox and First Order Modal Logic', Erkenntnis 81: 87-104.

36. Risse, Th. 2010. A Community of Europeans? Transnational Identities and Public Spheres. Ithaca and London: Cornell University Press.

37. Rückert, H. 2004. 'A Solution to Fitch's Paradox of Knowability', in Logic, Epistemology and the Unity of Science, eds. S. Rahman et al. Dordrecht: Springer Science+Business Media B.V., 351-380.

38. Schelsky, H. 1998 [1961]. „Žmogus ir visuomenè technikos gniaužtuose“, in Technikos filosofijos įvadas, ed. J. Mureika. Vilnius: Alma litera.

39. Scheuer, B.; Maziarz, M. 2019. 'Philosophy of Economics: The Constructivist and Scientific Realist Interpretation of Macroeconomics', Philosophy. Sociology 30(1): 8-16.

40. Schutz, A. 1953. 'Common-Sense and Scientific Interpretation of Human Action' Philosophy and Phenomenological Research 14(1): 1-38.

41. Schutz, A. 1967. The Phenomenology of the Social World. Trans. T. G. Walsh and F. Lehnert. Evanston: Northwest University Press.

42. Sennett, R. 2006. The Culture of the New Capitalism. New Haven: Yale University Press.

43. Shaw, R. K. 2011. 'The Nature of Democratic Decision Making and the Democratic Panacea', Policy Futures in Education 9(1): 123-129.

44. Spencer, D. A. 2018. 'Fear and Hope in an Age of Mass Automation: Debating the Future of Work', New Technology, Work and Employment 33(1): 1-12.

45. Traugott, E. C. 2019. Constructional Pattern-development in Language Change. Berlin: Mouton de Gruyter.

46. Turner, K. J. 2019. 'On Subjectivity and Objectivity in the Mengzi - Or Realism with a Confucian Face', Asian Philosophy 29(4): 351-362.

47. Vella, D., Gualeni, S. 2019. 'Virtual Subjectivity: Existence and Projectuality in Virtual Worlds', Techné: Research in Philosophy and Technology 23(2): 115-136.

48. Verhaeghe, P. 2012. What Abour Me? The Struggle for Identity in a Market-based Society. Trans. J. HedleyPrôle. London: Scribe.

49. Vydūnas. 1992 [1923]. Tautos laisvè ir reikšmè, in Raštai, t. III. Vilnius: Mintis.

50. Yusoff, W. F. W.; Kian, T. S.; Idris, M. T. M. 2013. 'Herzberg's Two Factors Theory on Work Motivation: Does it Work for Today's Environment?', Global Journal of Commerce \& Management Perspective 2(15): $18-22$. 
VYTIS VALATKA

\title{
Filosofiniai apmąstymai: kognityviniai, politiniai ir socialiniai aspektai
}

\begin{abstract}
Santrauka
Straipsnis nagrinèja ịvairias jungtis ir sąsajas tarp filosofijos ir kitų mokslų - lingvistikos, kognityvinių mokslų, sociologijos, ekonomikos, politinių, ideologinių ir žmogiškojo gyvenimo tyrimų. Minètos jungtys ir sąsajos analizuojamos trijose metodologinèse paradigmose. Pirmoji paradigma susieja pažinimą, apibrěžimą ir kalbejimą. Antroji - integruoja surinkimą, saviorganizavimą ir socialinę inžineriją, o trečioji apjungia darbą, gyvenimą ir bendrą pajautą. Remiantis minètomis paradigmomis, šis žurnalo numeris padalytas $\mathfrak{i}$ tris skyrius. Trumpi straipsnių pristatymai susieja tokias skirtingų mokslų problemas kaip pažinumo paradoksai, patikimi transdisciplinarinio mokslinio žinojimo apibrèžimai, lingvistinio subjektyvumo realizacijos priemonès ir mechanizmai, demokratijos saviorganizacijos efektyvūs būdai ir procedūros, ị demokratinès gerovès valstybès stiprinimą nukreiptos socialinès inžinerijos metodai, pagrịsti sèkmingo tolesnio europeizacijos proceso scenarijai, pusiausvyros tarp darbo, poilsio ir sveikatos įtvirtinimas, sveiko proto (common sense) fenomeno sutapatinimas su socialiniu gyvenamuoju pasauliu.
\end{abstract}

Raktažodžiai: filosofija, lingvistika, kognityviniai mokslai, sociologija, ekonomika, politiniai, ideologiniai ir žmogiškojo gyvenimo tyrimai, paradigma 